\title{
pKa and Ka (Acid dissociation constant)
}

\section{G Manjooran}

Department of Anaesthesia, University of the Witwatersrand, South Africa

Corresponding author, email: gracemanjooran@gmail.com

\section{Definition}

$\mathrm{pK}_{\mathrm{a}}$ of a drug is the $\mathrm{pH}$ at which $50 \%$ of the drug is ionised and $50 \%$ is not ionised/unionised..$^{1,2}$

The $\mathrm{pK}_{\mathrm{a}}$ is specific for each drug and these properties determine how a drug can be administered, the speed of absorption as well as speed of excretion by the kidneys. ${ }^{2}$

Keywords: pKa, Ka, acid dissociation constant

\section{Back to basics: acids and bases}

In an aqueous solution:
$\mathbf{H A} \leftrightarrow \mathbf{H}^{+}+\mathbf{A}^{-}$
$\mathbf{B}+\mathbf{H}^{+} \leftrightarrow \mathbf{B H}^{+}$
Acid $\leftrightarrow$ proton + conjugate base
Base + proton $\leftrightarrow$ conjugate acid

$\mathrm{pH}=-\log \left[\mathrm{H}^{+}\right]$: where $\left[\mathrm{H}^{+}\right]$is the concentration of free protons in the solution.

Therefore, a low $\mathrm{pH}=$ acidic where $\left[\mathrm{H}^{+}\right]$is high and a high $\mathrm{pH}=$ basic/alkaline where $\left[\mathrm{H}^{+}\right]$is low. The $\mathrm{pH}$ scale ranges from 0-14. An acid has a pH less than 7 and a base has a pH greater than 7 .

\section{$\mathrm{K}_{\mathrm{a}}$ : Acid dissociation constant}

$\mathbf{H A}(\mathrm{aq})+\mathbf{H}_{2} \mathbf{O}(\mathrm{l}) \leftrightarrow \mathbf{H}_{3} \mathbf{O}^{+}(\mathrm{aq})+\mathbf{A}^{-}(\mathrm{aq}) \quad \mathbf{K}_{\mathrm{a}}=\left[\mathbf{A}^{-}\right]\left[\mathbf{H}_{3} \mathbf{O}^{+}\right] /[\mathbf{H A}]$

In a reversible acid-base reaction, you can determine its $\mathrm{K}_{\mathrm{eq}}$ (equilibrium constant) or $\mathrm{K}_{\mathrm{a}}$. The $\mathrm{K}_{\mathrm{a}}$ is constant and only changes with temperature. ${ }^{3}$

The difference between a strong acid and a weak acid is the strong acid's ability to completely dissociate in an aqueous solution. If the acid base reaction favoured the left (higher [HA]) then you would have smaller concentrations of both $\left[\mathrm{A}^{-}\right]$and $\left[\mathrm{H}_{3} \mathrm{O}^{+}\right]$, which would result in a lower $\mathrm{K}_{\mathrm{a}}$ value. Therefore, the higher the $\mathrm{K}_{\mathrm{a}}$, the stronger the acid. The lower the $K_{a}$, the weaker the acid.

$p K_{a}=-\log \left[K_{a}\right]$

Therefore, the lower the $\mathrm{pK}_{\mathrm{a}}$ the stronger the acid. The higher the $\mathrm{pK}_{\mathrm{a}^{\prime}}$ the weaker the acid.

Most drugs are weak acids or bases. Weak acids and weak bases switch between their ionised and deionised states depending on the $\mathrm{pH}$ of the surrounding environment. ${ }^{1,2}$

Henderson Hasselbach equation: $\mathbf{p H}=\mathbf{p K}_{\mathbf{a}}+\log \left[\mathbf{A}^{-}\right] /[\mathbf{H A}]$ (remember your maths where $\log [1]=0$ )

Based on the above, when the amount of acid $(H A)=$ amount of conjugate base $\left(A^{-}\right): \mathbf{p H}=\mathbf{p K}_{\mathbf{a}}{ }^{4}$
Back to the beginning: The $\mathrm{pK}_{\mathrm{a}}$ of a drug is the $\mathrm{pH}$ at which $50 \%$ of the drug is ionised and $50 \%$ is unionised. ${ }^{1,2}$

An ionised/charged molecule is water soluble and cannot cross a cell membrane' (which is made of lipid), therefore it is dissolved inside cells, in the blood stream or urine.

An unionised molecule is lipid soluble and can cross cell membranes, ${ }^{1}$ therefore it easily passes through/is absorbed by cells and tissues.

\section{Example: aspirin}

Aspirin has a $\mathrm{pK}_{\mathrm{a}}$ of 3.5. Taken orally, it enters the stomach which is an acidic environment due to hydrochloric acid. Based on the information we have above, the aspirin will mostly be in the unionised form and thus lipid soluble. This means that it will be easily absorbed through the cells of the stomach and into the bloodstream. The $\mathrm{pH}$ of the blood stream is higher (7.4), thus the aspirin molecule will lose its $\left[\mathrm{H}^{+}\right]$and become ionised. The ionised form is then carried to its site of action, binds to other receptors, or is excreted in the urine. ${ }^{2}$

\section{Conflict of interest}

The author declares no conflict of interest.

\section{Funding source}

None.

\section{ORCID}

G Manjooran (iD https://orcid.org/0000-0002-9838-4676

\section{References}

1. Paul A. Drug absorption and bioavailability. In: Raj $G$, Raveendran R, editors. Introduction to basics of pharmacology and toxicology. Singapore: Springer, 2019. p. 81-8. https://doi.org/10.1007/978-981-32-9779-1 5

2. Peck T, Hill S. Pharmacology for anaesthesia and intensive care. Cambridge: Cambridge University Press; 2014. https://doi.org/10.1017/CBO9781107477605

3. Morgan G, Mikhael M, Murray M. Clinical anaesthesiology. New York: Lange/ McGraw Hill; 2006.

4. Drasner K. Local anesthetics. In: Katzung B, Trevor A, editors. Basic and clinical pharmacology. New York: Lange/McGraw Hill; 2015. p. 653-71. 